\title{
The "game" of glial fibrillary acidic and S100 proteins in pituitary adenomas: two players or several?
}

\author{
Oddziaływanie kwaśnego białka włókienkowego gleju i białka S100 \\ w gruczolakach przysadki mózgowej: dwóch czy więcej graczy?
}

\section{Anca Maria Cimpean ${ }^{1}$, Amalia Raluca Ceausu ${ }^{1}$, Ana Corlan², Eugen Melnic ${ }^{3}$, Andreea Adriana Jitariu ${ }^{1}$, Marius Raica ${ }^{1}$}

${ }^{1}$ Department of Microscopic Morphology/Histology, Angiogenesis Research Centre, "Victor Babes" University of Medicine and Pharmacy Timişoara, Romania

${ }^{2}$ Department of Endocrinology, VAsile Goldis University, Arad, Romania

${ }^{3}$ Department of Pathology, Nicolae Testemitanu University of Medicine and Pharmacy Chisinau, Moldova

\begin{abstract}
Introduction: S100 protein and GFAP expression in pituitary adenomas tumour cells is not well known; few correlations with other prognostic or therapeutic factors have previously been reported in pituitary adenomas. We aim to elucidate their involvement in the pathogenesis of pituitary adenomas and to establish the correlation of their expression with different growth factors and growth factor receptors known to have a prognostic and/or therapeutic role.

Material and methods: Sixty-one cases of pituitary adenomas were immunohistochemically assessed for the expression of GFAP and S100 protein in both tumour cells and FS cells, in close relationship with hormone profile, and correlated with vascular endothelial growth factor (VEGF) and epidermal growth factor receptor (EGFR) expression, previously studied by our team.

Results: GFAP and S100 protein were expressed both in tumour cells and FS cells. Differences between morphology, distribution, and density of GFAP+ FS cells and S100+ FS cells were observed according to the hormone profile of pituitary adenomas. GFAP and S100 protein expression in tumour cells was significantly related to hormone profile of pituitary adenomas and also with VEGF and EGFR expression. Conclusions: GFAP and S100 protein expressions in tumour cells from pituitary adenomas are influenced by hormone profile. Our results support the presence of two molecular subtypes of FS cells GFAP+/VEGF+/S100 respectively and another one that is GFAP-/S100+/ /EGFR+ simultaneously with the classical variant GFAP+/S100+. It is possible that S100+/EGFR+ pituitary adenomas represent a group of pituitary adenomas with an aggressive behaviour and a high ability of invasion and recurrence. (Endokrynol Pol 2017; 68 (4): 380-389) Keywords: S100 protein, GFAP, folliculostellate cells, pituitary adenomas
\end{abstract}

\section{Streszczenie}

Wstęp: Ekspresja białka S100 i kwaśnego białka włókienkowego gleju (GFAP, glial fibrillary acid protein) w gruczolakach przysadki mózgowej nie została dobrze poznana. Dostępne są nieliczne publikacje dotyczące korelacji tych cząsteczek z innymi czynnikami prognostycznymi lub terapeutycznymi w gruczolakach przysadki. Celem niniejszej pracy jest wyjaśnienie udziału tych białek w patogenezie gruczolaków przysadki i ustalenie korelacji między ich ekspresją a różnymi czynnikami wzrostu lub receptorami czynników wzrostu o znanej wartości prognostycznej i/lub terapeutycznej.

Materiał i metody: Sześćdziesiąt sześć przypadków gruczolaka przysadki zbadano metodami immunohistochemicznymi w celu oceny ekspresji białek GFAP i S100 zarówno w komórkach guza, jak i w komórkach pęcherzykowo-gwiaździstych (FS, folliculo-stellate cells) oraz przeanalizowania uzyskanych wyników w ścisłej zależności z profilami hormonalnymi gruczolaków i w korelacji z ekspresją czynnika wzrostu śródbłonka naczyniowego (VEGF, vascular endothelial growth factor) i receptora naskórkowego czynnika wzrostu (EGFR, epidermal growth factor receptor), ocenianych w badaniu przeprowadzonym wcześniej przez nasz zespół.

Wyniki: Ekspresję białek GFAP i S100 stwierdzono zarówno w komórkach guza, jak i w komórkach FS. Zaobserwowano różnice pod względem morfologii, rozkładu i gęstości komórek FS z dodatnią ekspresją białek GFAP i S100 (GFAP+FS i S100+FS) odpowiadające profilowi hormonalnemu gruczolaków przysadki. Ekspresja białek GFAP i S100 w komórkach guza była istotnie związana z profilem hormonalnym gruczolaków przysadki, a także z ekspresją VEGF i EGFR.

Wnioski: Ekspresja białek GFAP i S100 w komórkach gruczolaka przysadki zależy od profilu hormonalnego guza. Uzyskane w badaniu wyniki potwierdzają obecność dwóch podtypów molekularnych komórek FS GFAP+/VEGF+/S100 oraz jednego typu GFAP-/S100+/ /EGFR+ występujących jednocześnie z klasycznym wariantem GFAP+/S100+. Możliwe, że gruczolaki przysadki z ekspresją S100+/ /EGFR + należą do grupy tych nowotworów cechujących się agresywnością i dużą zdolnością do naciekania i nawrotów. (Endokrynol Pol 2017; 68 (4): 380-389)

Słowa kluczowe: białko S10, GFAP, komórki pęcherzykowo-gwiaździste, gruczolaki przysadki

Anca Maria Cimpean, MD, Ph.D., Hab. Dr., Professor of Histology, Department of Microscopic Morphology/Histology, Angiogenesis Research Centre, Piata Eftimie Murgu 2, 300041, Timişoara, Romania, phone: +40 720060955, e-mail: ancacimpean1972@yahoo.com 


\section{Introduction}

The normal pituitary gland is known to express a wide panel of immunohistochemical markers with a great heterogeneity of expression, which is region dependant. As has been experimentally demonstrated in specimens taken from the pars intermedia, ACTH type cells mostly express cytokeratins and vimentin [1]. All hormoneproducing cells are positive for cytokeratins, it appears that the folliculo-stellate cells from the adenohypophysis are selectively stained with CK19, while other regions contain EMA, sialomucin, and Leu-7-positive cells [1]. In a similar manner to the normal pituitary, adenomas show a differential expression of immunohistochemical markers. It has been demonstrated that most adenomas express cytokeratins [1]. In the same study, Kasper et al. [1] showed that co-expression of vimentin and neurofilament protein is rare in pituitary adenomas. Also, unlike the normal hypophysis, pituitary adenomas are negative for EMA and sialomucin but present an increased Leu-7 expression, which is encountered in the GH type and prolactin type of pituitary adenomas. Protein S100 and the glial fibrillary acidic protein (GFAP) in pituitary adenomas have been little studied. It appears that folliculo-stellate cells are positive for these two markers, most probably due to their glial origin [2]. It has been demonstrated that S100 protein is also expressed by the epithelial cells that line Rathke cysts and by some cells located in the pars tuberalis [2]. Moreover, a limited number of cells from Rathke cysts seem to co-express cytokeratins, protein S100, and GFAP, an aspect that is sometimes related to neoplastic changes [2]. Carcinogenesis in the pituitary gland seems to be enhanced by TNF-alpha and IL-6, as has been shown in invasive pituitary adenomas [3]. Other differential expressions have been noticed in ACTH type adenomas. It appears that these tumours present a diffuse positive reaction for CK20 and CK7, while TTF-1 expression was considered insignificant [4]. Only a few scattered literature data are found regarding the expression of protein S100 and GFAP in pituitary adenomas, but lot of information is available regarding their expression in tumours of the neurohypophysis [5-8]. Their expression in the pituitary tissue is limited to their description in the folliculo-stellate cells as well as in relation to the stem cells of the anterior pituitary gland. Folliculo-stellate cells are known to be controversial histological and pathological entities in both humans and mammals [9-11]. Folliculo-stellate cells have been reported as reactive players in pituitary adenomas [9] and possess a heterogenous S100 and GFAP expression, thus leading to the classification of subgroups with different phenotypes. It appears that, besides their role as sustentacular cells of the adeno- hypophysis, folliculo-stellate cells are characterised by a great plasticity and possess the ability to modulate the hypothalamo-hypophyseal-adrenal axis in special conditions [11, 12]. In spindle cell oncocytoma, a discussed pathologic entity, which seems to originate from folliculo-stellate cells, tumour cells are positive for S100 but, surprisingly, negative for GFAP [13-15]. Unlike spindle cell oncocytomas and adenomas of the anterior hypophysis, the adamantinomatous type of craniopharyngioma exhibits a positive GFAP reaction, while other tumour types appear to be negative for both S100 protein and GFAP but positive for TTF-1 $[16,17]$. GFAP, a marker of the neuroendocrine system, is strongly expressed in the neurohypophysis, namely by the granular cells and by the filament containing cells belonging to the choristoma, probably due to the fact that both cell types emerge from astrocytes [18]. S100 protein and GFAP expression in the tumour cells of pituitary adenomas is less studied, and the implication of these factors in the evolution and pathogenesis of pituitary adenomas has little been correlated with other prognostic or therapeutic factors that have previously been studied in pituitary adenomas. Besides protein S100 and GFAP, the neuroglial antigen 2 (NG-2) is another controversial marker in tumours of the pituitary gland. Normally, NG-2 is expressed by oligodendrocytes progenitors, pericytes, and tumour cells [19]. In pathological situations, this marker is exhibited by all tumour types of the adenohypophysis except for the ACTH type [19]. It has also been demonstrated that NG-2 modulates the prolactin type and the GH type adenomas through enhancement of cell adhesion but without influencing proliferation [19]. Previous data available in literature regarding pituitary pathology shows that a molecular mapping of the normal hypophysis, and of the various tumour types that emerge from it, serves as a useful tool for differential diagnosis and for the diagnosis of ectopic hormone-producing tissue and of metastases [20]. Based on these scattered literature data, the research that has been led in the present study has been initiated with the purpose of elucidating the implication of protein S100 and GFAP in the evolution and prognosis of pituitary adenomas, and to establish the correlation of their expression with different growth factors known as prognostic and/or therapeutic markers in several types of tumours but, also, less investigated in pituitary adenomas.

\section{Material and methods}

For our retrospective study, we selected 61 paraffinembedded specimens of pituitary adenomas based on accurate criteria regarding the pre-analytical stages, which included fixation, paraffin embedding proce- 
dures, and three-micrometer serial section performance. Histopathologic re-evaluation was performed by three experienced pathologists who examined the haematoxylin and eosin-stained slides and selected six additional sections from each case to establish the hormone profile of pituitary adenomas, growth hormone $(\mathrm{GH})$, prolactin (PRL), adrenocorticotropic hormone (ACTH), thyroid stimulating hormone (TSH), folliculo-stimulating hormone (FSH), and luteinising hormone (LH). Immunohistochemical procedures were performed to highlight all six pituitary hormones, i.e. growth hormone $(\mathrm{GH}$, polyclonal rabbit anti-human, dilution 1:300), prolactin (PRL, polyclonal rabbit antihuman, dilution $1: 250)$, adrenocorticotropin $(\mathrm{ACTH}$, monoclonal mouse anti-human, clone $02 \mathrm{~A} 3$, dilution $1: 50$ ), thyroid stimulating hormone (TSH, monoclonal mouse anti-human, clone 0042, dilution 1:50), luteinizing hormone $(\mathrm{LH}$, monoclonal mouse anti-human, clone C93, dilution 1:50), and follicle stimulating hormone (FSH, monoclonal mouse anti-human, clone C10, dilution $1: 50)$. All primary antibodies were supplied by Dako Cytomation, Carpinteria, USA.

Glial fibrillary acidic protein (monoclonal mouse anti human, clone GA5, ready to use, Novocastra) and S100 protein (rabbit polyclonal, Novocastra) were also performed by immunohistochemistry. All steps of immunohistochemical procedures were performed in an automated manner by using Bond Max Autostainer (Leica, Microsystems), having well standardised protocols specific for each antibody included in the present study.

Microscopic evaluation was made by two independent observers using a Nikon Eclipse E600 microscope (Nikon Corporation Japan). The images were captured and processed using a Lucia G system. For the evaluation of the hormone profile, more than $10 \%$ positive cells was considered a secreting tumour. Tumours presenting an increased GH, PRL expression were considered as a mamosomatotroph. GFAP and S100 protein were evaluated both in tumour cells and folliculostellate cells of the pituitary adenomas. Their expression was correlated with hormone profile and epidermal growth factor receptor (EGFR) previously studied on the same cases, and considering a potential therapeutic target for several tumours. Statistical analysis was made using the SPSS system version 17 . The statistical methods included correlation tests such as Pearson, Kendall, and Spearman. The correlations were considered statistically significant if the $p$ value was less than 0.05. A total correlation was considered when all three test groups presented significant values, and a partial correlation was considered when two out of three correlation tests presented statistical significance.

\section{Results}

GFAP expression was immunohistochemically quantified in the normal pituitary gland and in pituitary adenomas. GFAP heterogeneous expression correlated with the cell types and its distribution has been demonstrated. Initially, GFAP expression was described in the normal pituitary gland. Regarding the expression pattern, we encountered a cytoplasmic distribution of GFAP and a cytoplasmic combined with a membranar pattern in both endocrine and folliculo-stellate cells (FS) (Fig. 1a, b, c). In the acidophilic cells, GFAP was weakly expressed in the cytoplasm rarely with a membranar pattern. Inserted amongst these cell types, intensely positive cells were observed, with a chromophobe and basophilic morphology. FS were distributed amongst the endocrine cells but closely related to and surrounding capillary vessels and, as expected, had a different morphology with rare and short expansions that were strongly interconnected with the wall of the capillary vessel. FS cells were discontinuously distributed around the fenestrated capillary vessels, the contact between these cells and the capillary wall being made only through the expansions of the FS cells (Fig. 1d). FS cells density was relatively low, 2-4 cells/capillary vessel being observed. A particular aspect was observed in the area of the tuberal portion of the pituitary gland where the cells that lined the pseudofollicular structures were intensely positive for GFAP (Fig. 1e). Pituitary adenomas were characterised by a higher GFAP expression, compared with normal pituitary gland, but with the same distribution both in the tumour endocrine cells and in the FS cells, respectively.

From the total number of cases included in the study, $43.33 \%$ had a positive reaction for GFAP in tumour cells with low or moderate expression, with a strictly cytoplasmic location. The intensity of GFAP expression in FS cells was similar to that found in FS cells from the normal pituitary gland, but their number increased substantially compared with normal pituitary gland.

The distribution of GFAP-positive FS cells (GFAP + FS cells) was dependent on the hormone profile of the adenomas included in the study. Thus, in the adenomas with a GH or GH-PRL combined profile, the FS cells had a low density, being inserted amongst the tumour cells (Fig. 2a) that presented a low or moderate positive reaction for the same marker (Fig. 2b). In chromophobe cell adenomas, tumour cells were negative for GFAP, the intensity and the density of GFAP +FS cells being high. For ACTHsecreting adenomas, GFAP expression was restricted to the FS cells that presented a particular distribution, tumour cells being negative. An increase in the density of GFAP + FS cells was observed compared with normal pituitary gland. Their distribution was also specific; namely, they 


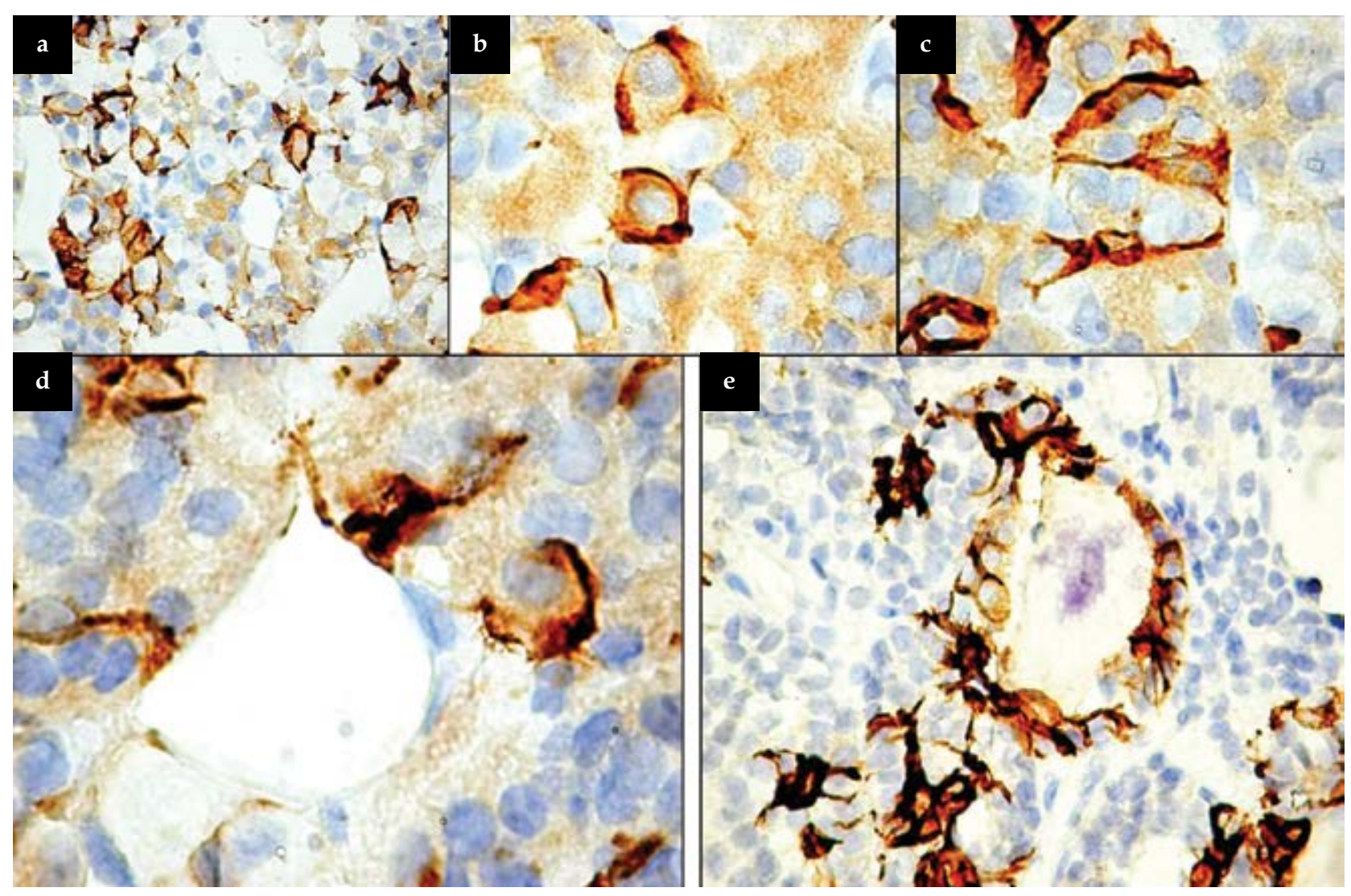

Figure 1. GFAP expression pattern in the normal pituitary gland. The heterogeneity of expression between the nests of endocrine cells (a), followed by a cytoplasmic expression pattern or cytoplasmic and membranous combined (b). In the stellate follicular cells (FS), the expression was intense and homogenous (c). Stellate follicular cells surrounding the capillary vessels, with their expansions attached to the wall of the blood vessel. Note the relatively low density of FS cells on the circumference of the capillary vessel (d). Pseudofollicular structures lined by GFAP positive cells, together with stellate follicular cells that are located around the pseudofollicular structures from the intermediate part of the pituitary gland (e)

Rycina 1. Ekspresja GFAP w prawidłowej przysadce. Zróżnicowanie ekspresji między gniazdami komórek endokrynnych (a); występuje ekspresja cytoplazmatyczna lub cytoplazmatyczna i błonowa (b). W komórkach pęcherzykowato-gwiaździstych (FS, stellate follicular) ekspresja jest intensywna i jednorodna (c). Komórki pęcherzykowo-gwiaździste otaczające naczynia włosowate; ekspansja zwiazana ze ściana naczynia krwionośnego. Należy zwrócić uwagę na stosunkowo mała gęstość komórek FS wokót naczynia włosowatego (d). Rzekomopęcherzykowe struktury wysłane komórkami GFAP-dodatnimi oraz komórki pęcherzykowato-gwiaździste rozmieszczone wokót struktur rzekomopęcherzykowych w pośredniej części przysadki (e)

were grouped around the blood vessels, with a tendency to form a relatively continuous layer around the capillary vessels (Fig. 2c). ACTH-secreting pituitary adenomas were characterised by the presence of vascular spaces, apparently not lined by endothelial cells, with the wall composed of tumour cells and palisading GFAP + FS cells (Fig. 2d). GFAP + FS cells belonging to ACTH-secreting adenomas presented an oval, elongated cell body that was inserted amongst tumour cells, with a characteristic "palisade-like" distribution, and which had the tendency to give sprouting expansions only from the cell pole opposite to the vascular or pseudo-vascular lumen.

The highest density of GFAP + FS cells was observed in plurihormonal pituitary adenomas, predominantly in the papillary type. GFAP+ FS cells formed in this case a well-organised network though the interrelation that they established with their cytoplasmic expansions (Fig. 2e).
The presence of GFAP+ FS cells in the normal pituitary tissue and in pituitary adenomas revealed a morphological heterogeneity that was dependent not only on the normal or the tumour status but also on the hormone profile of pituitary adenomas. Thus, in the normal pituitary tissue, GFAP + FS cells had an elongated cell body and presented short and rare expansions, interposed amongst endocrine cells or attached to the capillary wall (Fig. 2e, inset) compared with GH secreting pituitary adenomas, where GFAP+ FS cells presented an irregular body, mostly with a triangular aspect, with rare expansions, strongly attached to the adenoma tumour cells.

Starting from the microscopic observation of the morphological heterogeneity of the GFAP+ FS cells, we continued the study with the assessment of the correlation between GFAP expression and the hormone profile of pituitary adenomas, to identify the potential 


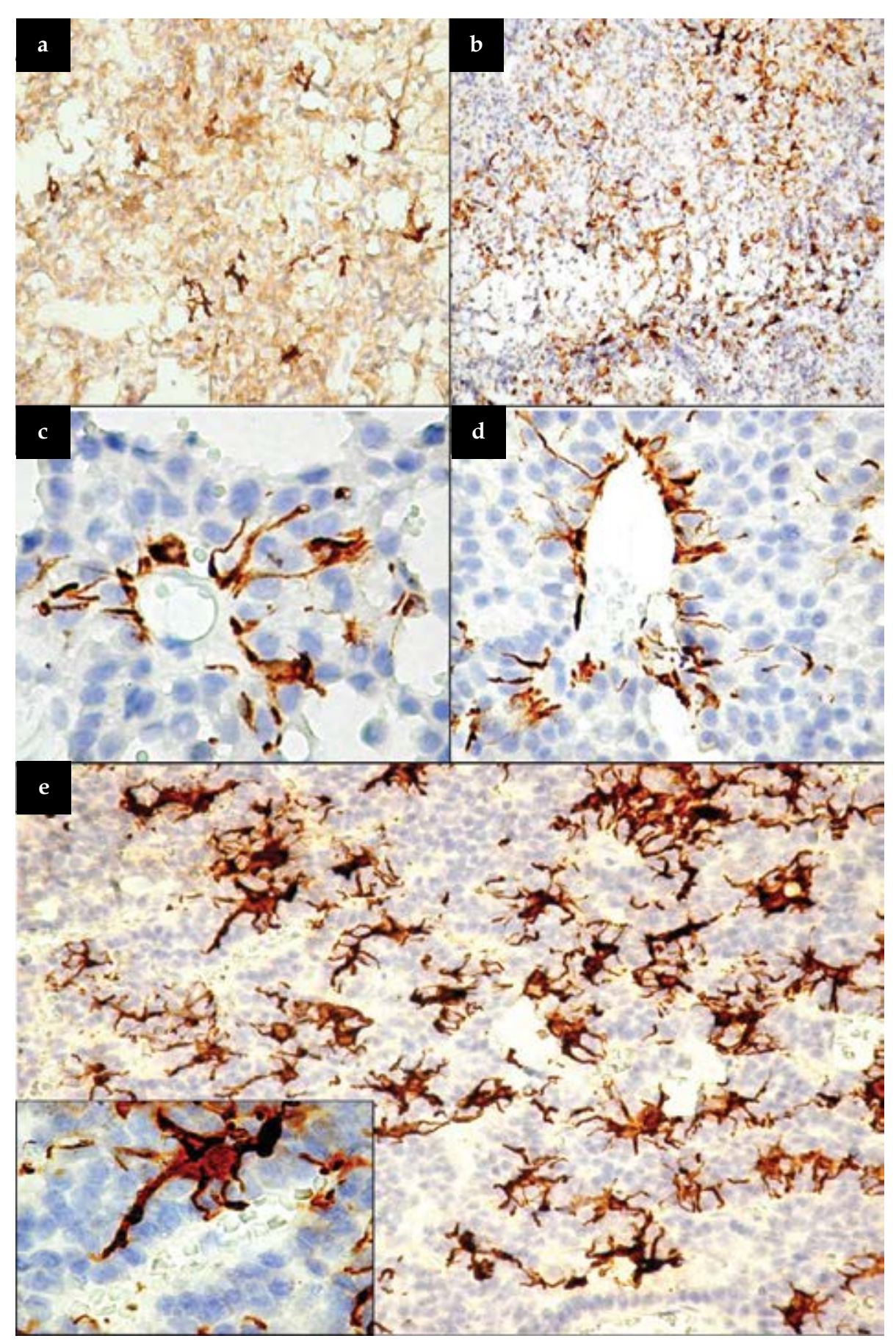

Figure 2. GFAP-positive tumour cells presenting a low and moderate intensity of reaction amongst which GFAP intensely positive stellate follicular cells are observed (a) in a GH-secreting pituitary adenoma. The high density of FS cells, GFAP positive, in an LH-secreting pituitary adenoma (b). FS cells with a perivascular distribution $(b)$ and with the tendency of forming, along with tumour cells, the wall that lines the pseudovascular spaces, characteristic for ACTH-secreting pituitary adenomas (c). The distribution of FS-GFAP+cells in plurihormonal pituitary adenomas. Note the high density and the network-like disposition given by the interconnections between the numerous expansions of the FS-GFAP+ cells (d). The interposition of tumour cells between the FS-GFAP+ cell expansions and the wall of the capillary vessel, which suggests disruption of the blood-brain barrier (d, inset).

Rycina 2. Gruczolak przysadki wydzielający GH (a): słabo lub umiarkowanie GFAP-dodatnie komórki guza, między którymi widoczne są silnie GFAP-dodatnie komórki pęcherzykowato-gwiaździste. Gęsto ułożone GFAP-dodatnie komórki FS w gruczolaku przysadki wydzielającym LH (b). Komórki FS rozmieszczone wokót naczyń krwionośnych (b) z tendencją do formowania, wraz z komórkami guza, ścian tworzących przestrzenie imitujące naczynia krwionośne, co jest charakterystyczne dla gruczolaków przysadki wydzielających ACTH (c). Rozkład komórek FS-GFAP+ w gruczolakach plurihormonalnych. Należy zwrócić uwagę na duża gęstość i sieciowy układ spowodowany połączeniami między licznymi rozrastającymi się komórkami FS-GFAP+ (d). Komórki guza znajdują się między rozrastającymi się komórkami FS-GFAP+ a ścianami naczyń krwionośnych, co sugeruje przerwanie bariery krew-mózg (d, wstawka) 
Table I. Statistical correlation between GFAP expression and GH-secreting pituitary adenomas Tabela I. Statystyczna korelacja między ekspresją GFAP a gruczolakami wydzielającymi GH

\begin{tabular}{|l|l|l|l|}
\hline & & GH & GFAP \\
\hline GH & Pearson correlation & 1.000 & 0.207 \\
\hline & Sig. (1-tailed) & - & $\mathbf{0 . 5 5}$ \\
\hline & N & 61 & 61 \\
\hline GFAP & Pearson correlation & 0.207 & 1.000 \\
\hline & Sig. (1-tailed) & 0.55 & - \\
\hline & N & 61 & 61 \\
\hline
\end{tabular}

\begin{tabular}{|l|l|l|l|l|}
\hline & & & GH & GFAP \\
\hline Kendall's tau_b & GH & Correlation coefficient & 1.000 & 0.194 \\
\hline & & Sig. (1-tailed) & - & $\mathbf{0 . 0 4 6}$ \\
\hline & & N & 61 & 61 \\
\hline & GFAP & Correlation coefficient & 0.194 & 1.000 \\
\hline & & Sig. (1-tailed) & 0.046 & - \\
\hline & & N & 61 & 61 \\
\hline Spears'man rho & GH & Correlation coefficient & 1.000 & 0.218 \\
\hline & & Sig. (1-tailed) & - & $\mathbf{0 . 0 4 6}$ \\
\hline & & N & 61 & 61 \\
\hline & GFAP & Correlation coefficient & 0.218 & 1.000 \\
\hline & & Sig. (1-tailed) & 0.046 & - \\
\hline & & N & 61 & 61 \\
\hline
\end{tabular}

Table 2. Statistical correlation between GFAP expression and ACTH-secreting pituitary adenomas Tabela 2. Statystyczna korelacja między ekspresją GFAP a gruczolakami wydzielającymi ACTH

\begin{tabular}{|l|l|l|l|}
\hline GFAP & Pearson correlation & 1.000 & 0.276 \\
\hline & Sig. (2-tailed) & - & $\mathbf{0 . 0 3 1}$ \\
\hline & N & 61 & 61 \\
\hline ACTH & Pearson correlation & 0.276 & 1.000 \\
\hline & Sig. (2-tailed) & 0.031 & - \\
\hline a & N & 61 & 61 \\
\hline \multicolumn{5}{|l}{} \\
\hline & \multicolumn{5}{l}{} \\
\hline GFAP & Pearson correlation & 1.000 & 0.203 \\
\hline & Sig. (1-tailed) & - & $\mathbf{0 . 0 5 8}$ \\
\hline & N & 61 & 61 \\
\hline LH & Pearson correlation & 0.203 & 1.000 \\
\hline & Sig. (1-tailed) & 0.058 & - \\
\hline C & N & 61 & 61 \\
\hline
\end{tabular}

\begin{tabular}{|l|l|l|l|l|}
\hline Kendall's tau_b & GFAP & Correlation coefficient & 1.000 & 0.296 \\
\hline & & Sig. (2-tailed) & - & $\mathbf{0 . 0 1 2}$ \\
\hline & & N & 61 & 61 \\
\hline & ACTH & Correlation coefficient & 0.296 & 1.000 \\
& & & & \\
\hline & & Sig. (1-tailed) & 0.012 & - \\
\hline & & N & 61 & 61 \\
\hline Spears'man rho & GFAP & Correlation coefficient & 1.000 & 0.325 \\
\hline & & Sig. (2-tailed) & - & 0.011 \\
\hline & & N & 61 & 61 \\
\hline & GFAP & Correlation coefficient & 0.325 & 1.000 \\
\hline & & Sig. (2-tailed) & 0.046 & - \\
\hline b & & N & 61 & 61 \\
\hline
\end{tabular}

influences of the pituitary hormones on the GFAP + FS cell variability. Amongst all pituitary hormones, GH-expressing pituitary adenomas presented a significant but low correlation with GFAP expression ( $p=0.05$ for Pearson index), but significant for Kendall and Spearman indexes (Table I). A strong correlation was also registered between ACTH and GFAP expression, thus the correlation index was statistically significant, at 12 (Table IIa, b). A low correlation was also present in that which considers LH (Table IIc). Regarding the other molecular markers included in the study, we registered an inversed correlation between GFAP expression and that of oncoprotein HER2 ( $p=0.025)$. EGFR overex- pression did not significantly overlap GFAP expression from a statistical point of view $(p=0.072)$. On the other hand, we registered a very strong correlation between GFAP and VEGF overexpression in pituitary adenomas $(\mathrm{p}=0.0014)$.

S100 protein in pituitary adenomas was also studied by using the immunohistochemical method on the normal pituitary gland and in pituitary adenomas. S100 protein had a nuclear and cytoplasmic pattern, being positive in the FS cells but also in the endocrine cells of the normal pituitary gland and the adenoma ones. The combined nuclear/cytoplasmic pattern was observed in tumour cells for about $19.5 \%$ of S100-positive cases; 

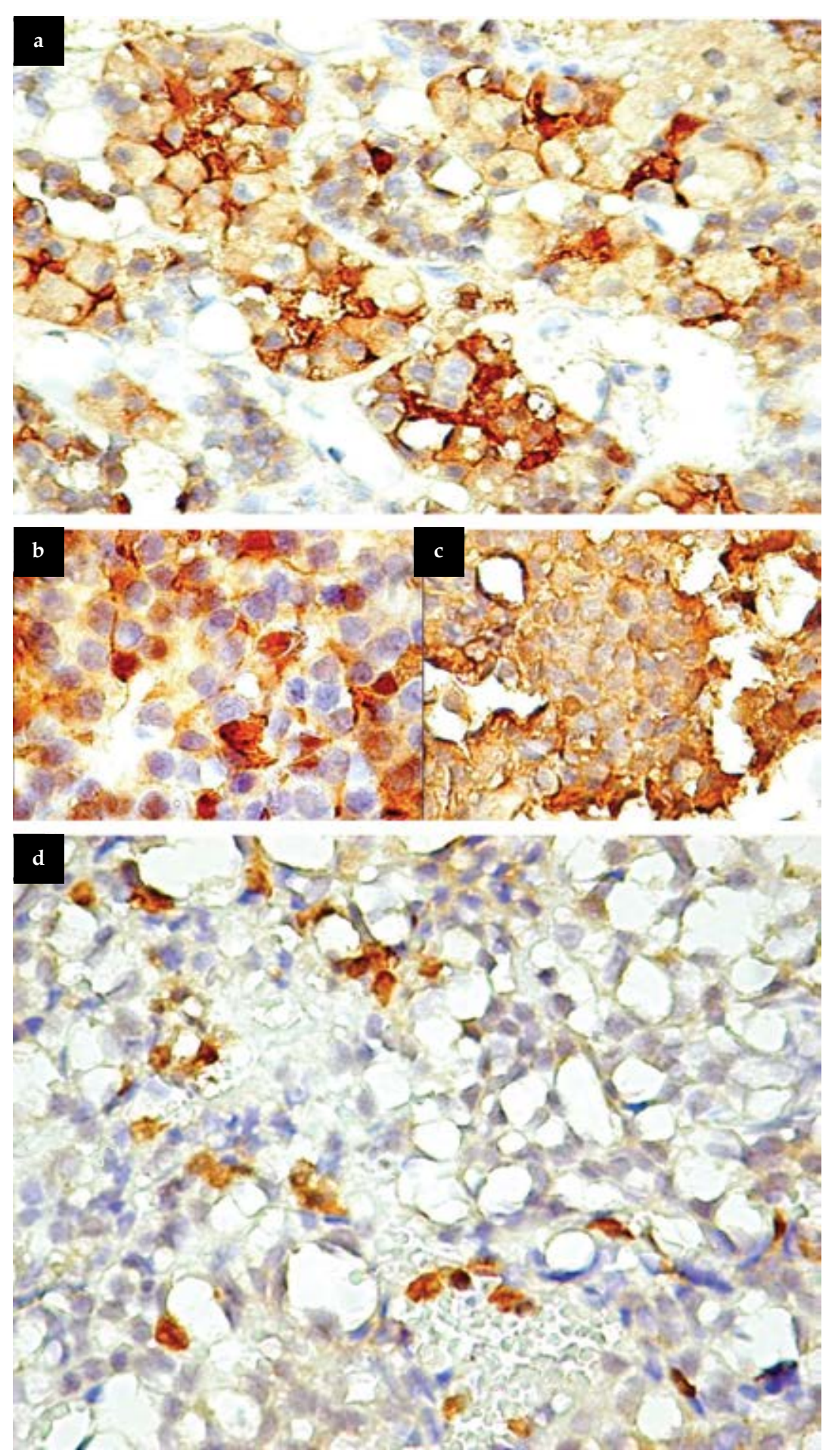

Figure 3. The expression of protein $S 100$ in the normal pituitary gland. Note the intense, nuclear, and cytoplasmic expression in the stellate follicular cells and the moderate cytoplasm-restricted expression in the endocrine cells, with an acidophilic pattern on HE and a low intensity in chromophobe cells (a). The variability of protein S100 expression in GH-secreting pituitary adenomas: intense, nuclear, and cytoplasmic (b), intense, cytoplasmic (c). Chromophobe type pituitary adenoma with chromophobe cells negative for protein S100 in their cytoplasm, with a focal and heterogenous expression in the nuclei of the chromophobe cells and in the cytoplasm, and the nucleus of FS cells inserted amongst chromophobe cells

Rycina 3. Ekspresja białka S100 w prawidtowej przysadce. Należy zwrócić uwagę na silna ekspresję w jądrze i cytoplazmie komórek pęcherzykowo-gwiaździstych oraz umiarkowana ekspresję ograniczona do cytoplazmy w komórkach endokrynnych z wybarwieniem kwasochtonnym w preparatach barwionych HE i matą ekspresję w komórkach barwnikoopornych (a). Zróżnicowanie ekspresji białka S100 w gruczolakach przysadki wydzielających GH: silna ekspresja w jądrze komórkowym i cytoplazmie, (b) silna ekspresja w cytoplazmie. (c) Barwnikooporny gruczolak przysadki z komórkami barwnikoopornymi niewykazujacymi cytoplazmatycznej ekspresji białka S100; widoczna ogniskowa, heterogenna ekspresja jądrowa w komórkach barwnikoopornych oraz ekspresja cytoplazmatyczna $i$ jądrowa w komórkach FS znajdujacymi się między komórkami barwnikoopornymi 
the remaining cases presenting a cytoplasmic-restricted expression.

The percentage of S100-positive cases was $66.12 \%$ from the total number of cases. Amongst these, 39.02\% presented a compact growth pattern, $39.04 \%$ were of papillary type, $9.75 \%$ presented a trabecular growth pattern, $4.87 \%$ spindle-shaped, and $7.31 \%$ were of alveolar type. Papillary type pituitary adenomas registered the highest intensity of S100 protein expression in tumour cells. Except papillary type adenomas, in the majority of pituitary adenoma cases the intensity of the reaction was low and moderate, in comparison to the normal tissue (Fig. 3a). 34.2\% of S100-positive cases are composed of acidophilic cells. Pituitary adenomas with basophilic cells represented $26.8 \%$ of 5100 -positive cases, and for $39 \%$ of cases the chromophobe component was present forming pure chromophobe pituitary adenomas or mixed chromophobe-acidophilic/basophilic pituitary adenomas.

Regarding the particularities of the immunohistochemical expression of S100 protein, we observed variabilities in the presence, the intensity, and the distribution of this marker in relation to the hormone profile. GH-secreting pituitary adenomas proved to be extremely heterogenous in that which considers the expression of protein S100 in tumour cells. The cases ranged from the absence of its expression in tumour cells to a low expression, strictly located in the cytoplasm (Fig. 3b), or an intense expression in the entire tumour area, nuclear and cytoplasmic, or just cytoplasmic (Fig. 3c). In the case of pituitary adenomas with chromophobe cells, the expression of S100 protein was low in the cytoplasm of the chromophobe cells, being mostly nuclear restricted (Fig. 3d).

The particular aspect that we noticed regarding the expression of GFAP in ACTH-secreting pituitary adenomas repeated itself in the case of protein S100. Tumour cells were negative while, around the vascular spaces, S100-positive cells were distributed, having a nuclear and cytoplasmic expression, and morphology similar to that of GFAP+FS cells. The expansions of the S100+ FS cells were strongly attached to the wall of the blood vessels, being also interconnected each other. These interconnections created a network of S100-positive expansions amongst which tumour cells were distributed.

As in the case of $\mathrm{GH}$-secreting pituitary adenomas, the endothelial cells of the vessels located close to S100-positive cells had a positive reaction for S100 protein with a nuclear distribution. In the rest of the tumour mass the S100-positive cells with a FS morphology were rarely encountered in ACTH-secreting pituitary adenomas.

In relation to the hormone profile, none of the six markers used for immunohistochemical profiling significantly correlated from a statistical point of view with S100 protein expression. Amongst the growth factors and corresponding receptors previously studied by our team, S100 protein significantly correlated with EGFR expression in the cases where S100 protein presented a moderate or intense expression.

\section{Discussion}

GFAP and S100 protein were studied in pituitary adenomas, being frequently associated with FS cells [21, 22]. Their expression in tumour cells, separately quantified in various types of pituitary adenomas, represents a sporadic subject in literature and, for this reason, the correlations with the prognosis, long-term survival, recurrences, and therapeutic implications are extremely unconvincing at present. Increasing data suggest the ability of tumour endocrine and non-endocrine cells to transdifferentiate themselves in FS cells where the two markers overlap in that which considers their immunohistochemical expression, these FS cells actually being considered as pluripotent stem cells [23-25]. The 'retrodifferentiation' phenomenon was observed and described especially in the case of ACTH-secreting pituitary adenomas [24]. In our study we also observed a particular aspect of distribution, localisation and GFAP and S100 expression in the case of ACTHsecreting pituitary adenomas. FS cells, GFAP+/S100+ were distributed around the blood vessels or lined pseudovascular spaces. We noticed a slightly increased density of these cells through GFAP immunostaining compared to protein S100. This discrepancy was supported by statistical data that showed that only GFAP significantly correlated from a statistical point of view with the expression of $\mathrm{ACTH}$, while $\mathrm{S} 100$ protein did not present any statistically significant correlation, despite the distribution and morphology concordance. This discrepancy of expression suggests two hypotheses: (i) the existence of two subpopulations of FS cells, an immature one that expresses only S100 with a great differentiation capacity and a population of mature FS cells GFAP +/S100 + with a well-established role, namely to establish the interconnection between the endocrine cells and the fenestrated capillary vessels, considering their distribution and localisation previously described correlated with the late expression of GFAP compared to S100 protein; and (ii) the existence of the same cell population but one that may present more than one evolutionary phase. These hypotheses will be demonstrated or infirmed through the quantification of the markers used to show pluripotent stem cells in further studies.

As a paradox, the description of $\mathrm{S} 100$ protein expression and that of GFAP in the normal pituitary gland 
is restricted to the evaluation of FS cells. We have not found any data in the literature regarding differential GFAP and S100 protein expression in the endocrine cells of the normal human pituitary gland.

Nowadays there is an experimental model that supports the data that we found, regarding the correlation between GFAP, ACTH, and LH. This model demonstrated that the induction of Bmi 1 overexpression by GFAP induced, in the experimental murine model, the development of pituitary adenomas in the anterior and intermediate portions of the adenohypophysis [26]. Over $50 \%$ of pituitary adenomas overexpress Bmi1 [26], a percentage that overlaps with the percentage of GFAP + pituitary adenomas that we found in our study. It has been also demonstrated that such pituitary adenomas increase ACTH secretion, an aspect that is also in concordance with the data observed and quantified in the present study.

The statistically significant association between GFAP and VEGF did not come as a surprise, considering the fact that VEGF was initially isolated from the FS cells of bovine adenohypophysis [27] and, moreover, pituitary adenomas also expressed VEGF in the tumour cells. On the other hand, the lack of association between VEGF and protein S100 counterbalanced by the S100-EGFR association supports the presence of two distinct FS cell and adenoma cell populations with different functions and having a rather well defined prognostic and therapeutic role.

Moreover, S100-EGFR association represents an unfavourable prognostic factor that stimulates the proliferation, invasion, and metastasis of tumour cells in hepatocellular carcinomas [28], glioblastomas [29], and melanomas [30]. Pituitary adenomas were not characterised from this point of view until now. Our data suggest the implication of this mechanism in GH-secreting pituitary adenomas and probably in PRL secreting ones also, but these data must be validated through further studies.

\section{Conclusions}

GFAP and protein S100 expression in tumour cells is implicated in the pathogenesis of the GH-and PRLsecreting pituitary adenomas, the mechanisms of activation being nowadays incompletely studied. This aspect seems to represent an unfavourable prognostic factor that governs the retro-differentiation phenomenon and supports the presence of pluripotent stem cells. Our results support the presence of two molecular subtypes of FS cells GFAP+/VEGF+/S100 respectively and another one that is GFAP-/S100+/EGFR+ simultaneously with the classical variant GFAP+/S100+. Through analogy with the observations obtained in other tumour types, it is possible that S100+/EGFR+ pituitary adenomas represent a group of pituitary adenomas with aggressive behaviour and a high ability of invasion and recurrence, aspects that represent an unfavourable prognostic factor. The GFAP-ACTH-LH axis is studied only in experimental models presently, but it seems to favour the development of pituitary adenomas in the anterior and intermediate regions of the adenohypophysis, adenomas that are characterised by an unfavourable prognosis.

\section{Acknowledgments}

Conflict of interests: none declared.The present work was supported by internal funds provided by Victor Babes University of Medicine and Pharmacy, Timisoara, Romania.

\section{References}

1. Kasper M, Kasper M, Kern F, et al. Immunohistochemical studies on human pituitary gland and adenomas. J Hirnforsch. 1991; 32(6): 725-734, indexed in Pubmed: 1821419.

2. Marin F, Boya J, Lopez-Carbonell A, et al. Immunohistochemical localization of intermediate filament and S-100 proteins in several nonendocrine cells of the human pituitary gland. Arch Histol Cytol. 1989; 52(3): 241-248, indexed in Pubmed: 2476166.

3. Wu JL, Qiao JY, Duan QH. Significance of TNF- and IL-6 expression in invasive pituitary adenomas. Genet Mol Res. 2016; 15(1), doi: 10.4238/ gmr.15017502, indexed in Pubmed: 27050975.

4. Cykowski MD, Takei H, Baskin DS, et al. Epithelial and organ-related marker expression in pituitary adenomas. Neuropathology. 2016; 36(4): 354-364, doi: 10.1111/neup.12284, indexed in Pubmed: 26991787.

5. Phillips JJ, Misra A, Feuerstein BG, et al. Pituicytoma: characterization of a unique neoplasm by histology, immunohistochemistry, ultrastructure, and array-based comparative genomic hybridization. Arch Pathol Lab Med. 2010; 134(7): 1063-1069, doi: 10.1043/2009-0167-CR.1, indexed in Pubmed: 20586639 .

6. Zhang F, Chen J, You C. Pituicytoma: case report and review of the literature. Neurol India. 2010; 58(5): 799-801, doi: 10.4103/0028-3886.72187, indexed in Pubmed: 21045523.

7. Kwon MiJ, Suh YL. Pituicytoma with unusual histological features. Pathol Int. 2011; 61(10): 598-602, doi: 10.1111/j.1440-1827.2011.02708.x, indexed in Pubmed: 21951670.

8. Ida CM, Yan X, Jentoft ME, et al. Pituicytoma with gelsolin amyloid deposition. Endocr Pathol. 2013; 24(3): 149-155, doi: 10.1007/s12022-0139254-y, indexed in Pubmed: 23817895

9. Giometto B, Miotto D, Botteri M, et al. Folliculo-stellate cells of human pituitary adenomas: immunohistochemical study of the monocyte/ macrophage phenotype expression. Neuroendocrinology. 1997; 65(1): 47-52, indexed in Pubmed: 9032773.

10. Jovanović I, Ugrenović S, Ljubomirović M, et al. Folliculo-stellate cells - potential mediators of the inflammaging-induced hyperactivity of the hypothalamic-pituitary-adrenal axis in healthy elderly individuals. Med Hypotheses. 2014; 83(4): 501-505, doi: 10.1016/j.mehy.2014.08.018, indexed in Pubmed: 25175404.

11. Sakuma E, Wada I, Soji T, et al. The changes of gap junctions between pituitary folliculo-stellate cells during the postnatal development of Zucker fatty and lean rats. Microsc Res Tech. 2014; 77(1): 31-36, indexed in Pubmed: 24738148.

12. Kapitonova MIu, Ullah M, Kuznetsov SL, et al. [Age-related changes of the pituitary folliculo-stellate cells in rats in chronic stress]. Vestn Ross Akad Med Nauk. 2013(11): 98-102, indexed in Pubmed: 24640738.

13. Vajtai I, Beck J, Kappeler A, et al. Spindle cell oncocytoma of the pituitary gland with follicle-like component: organotypic differentiation to support its origin from folliculo-stellate cells. Acta Neuropathol. 2011; 122(2): 253-258, doi: 10.1007/s00401-011-0835-x, indexed in Pubmed: 21590491.

14. Borota OC, Scheithauer BW, Fougner SL, et al. Spindle cell oncocytoma of the adenohypophysis: report of a case with marked cellular atypia and recurrence despite adjuvant treatment. Clin Neuropathol. 2009; 28(2): 91-95, indexed in Pubmed: 19353839.

15. Alexandrescu S, Brown RE, Tandon N, et al. Neuron precursor features of spindle cell oncocytoma of adenohypophysis. Ann Clin Lab Sci. 2012; 42(2): 123-129, indexed in Pubmed: 22585606. 
16. Yoshimoto T, Takahashi-Fujigasaki J, Inoshita N, et al. TTF-1-positive oncocytic sellar tumor with follicle formation/ependymal differentiation: non-adenomatous tumor capable of two different interpretations as a pituicytoma or a spindle cell oncocytoma. Brain Tumor Pathol. 2015; 32(3) 221-227, doi: 10.1007/s10014-015-0219-3, indexed in Pubmed: 25893822.

17. Burghaus S, Hölsken A, Buchfelder M, et al. A tumor-specific cellula environment at the brain invasion border of adamantinomatous craniopharyngiomas. Virchows Arch. 2010; 456(3): 287-300, doi: 10.1007 s00428-009-0873-0, indexed in Pubmed: 20069432.

18. Vinores SA. Demonstration of glial fibrillary acidic (GFA) protein by electron immunocytochemistry in the granular cells of a choristoma of the neurohypophysis. Histochemistry. 1991; 96(3): 265-269, doi: $10.1007 / \mathrm{bf00271546.}$

19. Tateno T, Nakano-Tateno T, Ezzat $S$, et al. NG2 targets tumorigenic Rb inactivation in Pit1-lineage pituitary cells. Endocr Relat Cancer. 2016, 23(5): 445-456, doi: 10.1530/ERC-16-0013, indexed in Pubmed: 27048321.

20. de Herder WW. Molecular Imaging of Pituitary Pathology. Front Horm Res. 2016; 45: 133-141, doi: 10.1159/000442329, indexed in Pubmed: $\underline{27002335}$.

21. Inoue K, Couch EF, Takano K, et al. The structure and function of folliculo-stellate cells in the anterior pituitary gland. Arch Histol Cytol. 1999; 62(3): 205-218, doi: 10.1679/aohc.62.205, indexed in Pubmed: 10495875.

22. Devnath S, Inoue K. An insight to pituitary folliculo-stellate cells. J Neuroendocrinol. 2008; 20(6): 687-691, doi: 10.1111/j.1365-2826.2008.01716.x indexed in Pubmed: 18601690.

23. Horvath E, Kovacs K. Folliculo-stellate cells of the human pituitary: a type of adult stem cell? Ultrastruct Pathol. 2002; 26(4): 219-228, doi: $\underline{10.1080 / 01913120290104476}$, indexed in Pubmed: 12227947.
24. Min HS, Lee SJ, Kim SK, et al. Pituitary adenoma with rich folliculostellate cells and mucin-producing epithelia arising in a 2-year-old girl. Pathol Int. 2007; 57(9): 600-605, doi: 10.1111/j.1440-1827.2007.02145.x indexed in Pubmed: 17685932.

25. Fu Q, Gremeaux L, Luque RM, et al. The adult pituitary shows stem/ progenitor cell activation in response to injury and is capable of regeneration. Endocrinology. 2012; 153(7): 3224-3235, doi: 10.1210/en.20121152, indexed in Pubmed: 22518061.

26. Westerman BA, Blom M, Tanger E, et al. GFAP-Cre-mediated transgenic activation of Bmi1 results in pituitary tumors. PLoS One. 2012 7(5): e35943, doi: 10.1371/journal.pone.0035943, indexed in Pubmed: 22574128 .

27. Gospodarowicz D, Lau K. Pituitary follicular cells secrete both vascular endothelial growth factor and follistatin. Biochemical and Biophysical Research Communications. 1989; 165(1): 292-298, doi: 10.1016/0006291x(89)91068-1.

28. Luo X, Xie H, Long X, et al. EGFRvIII mediates hepatocellular carcinoma cell invasion by promoting S100 calcium binding protein A11 expression. PLoS One. 2013; 8(12): e83332, doi: 10.1371/journal.pone.0083332, indexed in Pubmed: 24376686.

29. Johnson H, Del Rosario AM, Bryson BD et al. Molecular characterization of EGFR and EGFRvIII signaling networks in human glioblastoma tumor xenografts. Mol Cell Proteomics. 2012; 11(12): 1724-1740, doi: 10.1074/ mcp.M112.019984, indexed in Pubmed: 22964225.

30. Weissinger SE, Keil P, Silvers DN, et al. A diagnostic algorithm to distinguish desmoplastic from spindle cell melanoma. Mod Pathol. 2014 27(4): 524-534, doi: 10.1038/modpathol.2013.162 indexed in Pubmed: 24051699 . 